\title{
The Implementation of Phonic Method for Enhancing Very Young Learners' Vocabulary
}

\author{
Getruida Nita Mozes \\ Politeknik Nusa Utara \\ Tahuna, Indonesia \\ mozesnita@gmai.com
}

\author{
Nihta V. F. Liando* \\ English Department \\ Universitas Negeri Manado \\ Tondano, Indonesia \\ *nihtaliando@unima.ac.id
}

\begin{abstract}
Teaching a foreign language especially vocabulary for very young learners are more challenging than teaching an adult. Interesting and fun activities are needed for very young learners to enhance their abilities to learn new foreign language vocabulary. If teachers do not use appropriate teaching methods to teach English vocabulary, the achievement of the learning process may not work well. One of the methods that can be used is the phonic method. This study intends to find out the effect of the phonics method to enhance very young learners' English vocabulary. This is qualitative research. The population of this research is 15 children of one playgroup in Tahuna Sangihe Regency, who are 4 to 5 years old. This research data is learning activity at single-letter-sound. The research data are learning activity at single-letter-sound. In every activity, young learners are introduced three single-letter-phonics sound at the beginning of the words. There are two steps to do this activity; 1 . To introduce a letter and its phonic sound. 2. New words gaining. As a result of this research young learners are easy to pronounce correctly and remember the letters and its sound, and the words. The result shows that the phonic method could enhance these young learners' vocabulary.
\end{abstract}

Keywords: vocabulary, young learners, phonic method

\section{INTRODUCTION}

Early childhood education can play an essential role to prepare very young learners (VYLs) to study formal/informal education and later success in school. For that reason, one Play Group in Tahuna decided to include English as one subject in its curriculum.

To help Very Young Learners learn English as a foreign language, teaching methods and learning strategies should be influential for their emotion/ physic, various activities and short periods. At this age, learners' language ability develops through external stimulus. To reach that point, the phonic method is used in teaching-learning. To make it more effective; song, game, coloring, cutting, gluing, jazz chant and short story become its related technique to create various and fun activities in introducing how to pronounce a word in English and memorize it.

In this level, English is only taught to introduce some vocabularies that start with letters $\mathrm{Aa}$ to $\mathrm{Zz}$ and their phonic sound. They are not taught how to read long sentences or write because their literate mother tongue and basic concepts of their first language are still normally simple. Moreover, the function of their psychic and physic do not burgeon complete yet.

When the learners are introduced with English vocabularies, the focus is on their single- first letter of phonics sound. This activity is to exercise their ability to pronounce and memorize English words. When the learners are often trained on how to pronounce and use English in communication, their language ability can grow up in English utterance.

\section{VOCABULARY}

As one of the language components, vocabulary plays an important role in daily human life to make interact one to another and to understand speakers' culture and habitual.

Since vocabulary is important in language learning, interesting activities and a good environment are needed to influence very young learners' brains and motivation to master them. Vocabularies should be taught in a simple way and fun.

Teaching vocabulary is one of the basic facilities to help children to study a foreign language. Children require multiple exposures to words to develop a rich understanding of their meaning and use. Teachers should make a point of introducing interesting new words for children to learn into each classroom activity [1].

From new words that are taught for the very young learner, they become a bridge for them to familiarize themselves with the language uses in a simple way of daily communication, to know how to read a word and the word is written. Explanations of targeted vocabulary can support word learning $[2,3]$.

Vocabulary is an essential part of language learning and it is also a basic step to learn English in written form as well as spoken form. Vocabulary itself can be defined as a list of words for a particular language or set of words that individual speakers of language might use [4]. 
symbols that represent them (graphemes or letter groups) [11] And its related technics like games, songs, and short stories lead them to repetition. The aims of using this selected activity are to get very young learner motivation and participation in studying English Vocabulary.

The game can give a big result for learners' abilities. Through the game, children get various interesting experiences, at the same moment they study and develop their ability expansion [12]. The game can give a contribution to upgrade the learners' psychic and physic abilities.

Young children are physically active [8]. The injection into primary English teaching of physical movement for the sole purpose of letting off steam is an acknowledgment only of childish restlessness. But purposeful activity: action songs, dramatization, the coloring and drawing a picture, manipulating real objects and puppets, action games like 'Simon Says', quieter games like 'Picture Dominoes', the kind of role-playing found in children's play: these are the very stuff of the exploratory and expressive activity natural to the young child.

Very young learners, in this case, are playgroup students. They are between four to five years old. At this age, they need good treatment to help them to learn, so the environment of learning activity, method and technic should make them enjoy and fun. Their feeling can lead them to master English vocabulary. When we teach children, we have to remember that they are unique and can develop according to their ability [13]. Our duty as adults and teachers are; to motivate and give facilities when they are ready to learn new things. Teachers should make a point of introducing interesting new words for children to learn into each classroom activity [1].

Teaching vocabulary through phonics method, in this case, is just teaching children single-letter sounds in a word. Children are taught letter sounds in reception. This involves thinking about what single letter sound start in a word, saying the sound out load and then recognizing how that sound is represented by a letter.

They are taught in three main things;

- Introduce the name and sounds of Aa to $\mathrm{Zz}$ letter.

- Pronounce the first sounds of the single letter sound in a word.

- Recognize the word in which its first letter sound is pronounced.

This Phonics method is entirely used with its related technic; games, songs, and role-playing. The period is short for every activity. It is necessary to switch frequently from one activity to another during lessons: ten minutes is the longest time for which many primary children can sustain an interest in one activity [8]

\section{RESEARCH METHOD}

This research was conducted to describe the implementation of the phonic method for enhancing young learner vocabulary. This research used qualitative research teaching children to read linking sounds (phonemes) and the 
which emphasized among others on the meaning, the researcher as the main instrument, its data characteristics is descriptive, and the priority is the process than the results [14].

The population of this research is 15 students who are 4 to 5 years old at the Play Group in Tahuna Sangihe Regency in the academic year 2018-2019. The research data are learning activity at a single-letter-sound of the first letter of a vocabulary lesson. The class starts from 9 to 11 AM; 30 minutes is for pre activities, 1 hour is for main and closing activity (various activities and short period are used), 30 minutes for recess time. This research has been held for four months starting from August to December 2018. Techniques to collect the data are observation, recording, and taking notes. The procedures to analyze the data in qualitative research are data reduction, data display and conclusion/verification [15].

From that explanation, data analyzing procedures in this research are: 1) observing, recording, taking notes in the planning and the learning activities, 2) taking the suitable and needed data, 3) classifying the needed data, 4) interpreting and concluding the data that has identification and classified to decide the meaning of this research. If in the fourth step; the result of analyzing, interpretation, and conclusion, the goal is not reached, the researcher did again the first, second, and third steps.

For data validity investigation in this research, the researcher used the following techniques: (1) Prolongation participation, (2) Observation diligence, (3) Triangulation, (4) Discussing with a colleague [16].

The prolongation participation technique is done by the researcher to follow and to observe the vocabulary lesson for every meeting. The observation about the correct way of the students pronounce the words and take the first letter of a word, but the pictures that are mentioned in its first letterbox. With this observation diligence technique, the researcher could get complete data. The triangulation technique is done by the researcher to communicate with the students' parents or their baby sitter about the advantages of vocabulary lessons for their English vocabulary at home. Discussion technique through the meeting with a colleague at the end of every meeting. And the result of it, the researcher can get new data that was not observed by the researcher in the learning activities. Then, the researcher and her colleague make a lesson plan and prepare lesson material to do in the next learning activities.

\section{RESUlTS AND DISCUSSION}

There were two things were investigated in this study, first VYLs' reception and participation in the class and second classroom activity which engaged VYLs into more active. The details of the findings are discussed in the following detail.

\section{A. Classroom Procedures}

The English vocabulary lesson through the phonic method and its related technic were divided into 3 sessions.

1) Pre activity: The first activity is warming up; VYLs listen and very simple English song like "Good morning",
"Hello...hello" and jolly phonics song refers to single-letter sound. Next, the Teacher asks VYLs to come to the circle place sing and dance "circle song". The purpose of this activity is to enhance VYLs' vocabulary and exercise their organ of speech. This activity becomes a signal for YVL that the lesson will begin soon. After that, the teacher and VYLs sit in the praying position and sing praying songs. "Thank you for Your Love God".

2) Main activity: The teacher prepares some activities like sing songs, play games and exercises for the VYLs to pronounce first-letter phonic sound and word.

The first activity is introducing the English letter name of Aa to $\mathrm{Zz}$ through alphabet song. Every meeting VYLs only study three single-letter sounds and two target words. This activity starts with single letter sound $\mathrm{Aa}$ to $\mathrm{Cc}$ and next meeting single-letter sound Dd to Ff. It happens until $\mathrm{Aa}$ to $\mathrm{Zz}$ letter sound is taught. These activities are held in a short time 5 to 10 minutes.

English vocabulary lesson is divided into three sessions; 1. While VYLs watch how a letter is written, listen to the song of its name and its sound, and how it comes to a word, VYLs is trained to repeat/mime and sing along this song. For example; VYLs watch how to write letter Aa, listen its sound a... a... a... and observe a picture (that has a word under it) start with sound a... a... After that, VYLs practice how to pronounce the first letter sound of a word. 2. To strengthen VYLs' memory of the word. Playing a game is needed. The teacher distributes them into a group to play "find and gluing game" (this is one of the games that are prepared by the teacher). A group consists of 3 members. Before VYLs start to play, the teacher and her colleagues act the game procedure and show how to work in a team. The game procedures are; every group stands in the queue to start playing, the first learner who stands in the first line takes one letter and give it to next member, and she/he gives it to the last member to put it on its picture (this picture has its printed word). For the second letter, VYLs have to change their position. Last become the first, the first to second, second to last and follow the previous activities until all three letters are put on their picture. To make this game more fun and exacting, the phonic song of the selected first-letter sound from $\mathrm{CD}$ is played. Then, the teacher and her colleague yell to support for VYLs to make competition in playing.

3) Post-test: While VYLs are playing, the teacher and her colleagues observe their activities. When the game end teacher and VYLs check the result. The teacher took the letter, she asks VYLs to tell the letter name, pronounce its sound and stick it on the picture and say the word. The merit is given to the group who stick the letter in the right picture. 3. To evaluate VYLs' progress in gaining English vocabulary. The teacher leads them to sit on a chair and gives a paper with some pictures on it. The researcher used the capital and lowercase letter cards to show for VYLs and pronounce its sounds and mention the word. Students are asked to circle the picture that its first letter sound and its word is mentioned by 
the teacher. At the end of learning activity, VYLs watch and listen to short story single letter sound $\mathrm{Aa}, \mathrm{Bb}, \mathrm{Cc}$ from $\mathrm{CD}$.

The teacher uses "Sounds great single-letter sounds book and its CD", phonics song adapted from Jolly Phonics Program, and flashcard as sources to support vocabulary lessons.

\section{B. Identifying Single-letter Sound in Word}

The ability to hear sounds in words called phonological awareness. For example, when VYLs heard the word "ant", the student could hear sound "a". From the class observation, it helped students not only memorize the word and spell it properly, but also to understand how phonic works from firstletter sound to form a word.

In the practice stage, VYLs were encouraged to horn their first-letter sound by starting from a word which starts letter Aa to Cc. Every meeting three-letter phonic sounds are taught. The teacher used sound phonic audio, phonic song, and flashcard.

This percentage latter, VYLs was followed by practice to match the sound "a" to the correct picture that is the first-letter sound starts from a letter of "a". For example, the teacher pronounces "a" for "ant" VYLs pronounce "a" and find it to stick on its picture.

\section{Flashcard}

Students were more able to pronounce words Then they know the first-letter sound and its letter. The teacher showed two pictures and point out tricky pictures sounded out incorrectly. These pictures have to learn in the group.

In the presentation stage, VYLs is asked to look at the pictures and choose which one is correct. VYLs also encouraged to recall their knowledge of the first letter sound of the word and its letter.

\section{Games}

VYLs like playing, hence learning can be designed through playing as well. And VYLs cannot stay for a long period in concentration and focus for the topic is being taught, thus many games can be applied in phonic classes. To make fun and interesting every meeting the teacher change the game. Some games can use in phonic class: Hunt the letter sound game, in the game activities; when VYLs start to introduce first-letter sound during the classroom they can search the specific sounds pointed by the teacher. This way not only to enhance VYLs' understanding of the association between a letter and its sound but also the link between the letter sounds and word. Find and gluing game, in this activity, teachers pronounce first-letter sound in a group VYLs work together to find the letter that its sound is pronounced and gluing it on its picture. Simon Say game, in this activity teacher prepare three single-letter sound and action verbs: hop, touch, run to make various activities. The teacher pronounces the word "Simon say" let's hop to the letter sound "a". The pictures and its written word start with sound "a" are arranged on the floor. VYLs like to imitate teacher action, so the teacher gives an example of how the procedure of the game, she hopped to the word that its first- letter sound is pronounced. This activity is still run until all target first-letter sounds and its words master by VYLs. Picture clue game, in this activity teacher show flashcard, pronounce its first-letter sound and ask VYLs to follow letter line that its sound is pronounced at the end of the line to get the picture, VYLs should open its cover. This activity is run in a group. Hide and Seek, in this activity, all VYLs sit on the carpet bow down close their eyes, one learner takes a flashcard and hides it behind his friend, after that he cried out and pronounces the word that is hidden by him. All learner open their eyes and sing a song: who took "cat picture" on the picture box, mention of their friend's name example "Joel", teacher train them how to respond when their name is mentioned; "who me" and the others say "yes, you", Joel check it when the flashcard is not with him all learners sing and mention one of their friend's name again. It is run until the flashcard is found.

\section{E. Song}

This program used "Sound Great Single- Letter Sound" phonic audio video song;

$$
\begin{aligned}
& \text { "Aa" sound "a" "Aa" sound "a" a... a... a... } \\
& \text { "Bb" sound "b" "Bb" sound "b" b... b... b... }
\end{aligned}
$$

\section{CONCLUSION}

When phonics is taught with its related techniques, excellent results could happen, particularly in memorizing and pronouncing words. Phonics sessions

The research study on English vocabulary in the Play Group brings out many pieces of evidence on teaching foreign language vocabulary. Thus, from the discussion, it could be concluded that First, although the students do not say the word that the teacher asks them to pronounce during the posttest they can do it perfectly. It means that they can master the vocabulary and its first-letter sound.

Second, the advantages of early introduction of language on some language abilities but not all. Listening and pronunciation, in general, have better results for an earlier start, and in memorizing the words. $\mathbf{R} \mathbf{R}$

Finally, researchers also find out that cognitive development affects the language acquisition process as well as language development.

\section{REFERENCES}

[1] P.O. Tabors, One Child, Two Languages: A Guide for Early Childhood Educators of Children Learning English as a Second Language (2nd ed). Baltimore: Paul H. Brookes Publishing Co. 2008.

[2] Brabham and Lynch-Brown, "Effects of Teachers' Reading Aloud Styles on Vocabulary Acquisition and Comprehension of Students in the Early Elementary Grades," Journal of Education Psychology, vol. 94 , pp. 465-473, 2002. 
[9] D. Paul D, Song and Games for Children. New York: McMillan publishing Co. Inc., 1996.

[3] M.D. Coyne, Simmons, D.C. Kame'enui M. and Stoolmiller, "Teaching Vocabulary during Shared Storybook Readings: An Examination of Differential Effects," Exceptionality, vol. 12, no. 3, pp. 145-162, 2004.

[4] E. Hatch and C. Brown, Vocabulary, Semantics, and Language Vocabulary Education. Cambridge: Cambridge University Press, 1995.

[5] J. Piaget, The Science of Education and the Psychology of the Child. New York: Oxford, 1970.

[6] Borgia, T. Eileen, Schuler and Dorothy, "Action Research in Early Childhood Education ERIC Digest. [Online]. Retrieved from: http;//www.ericfacility.net/ericdigests/ed401047. 2003.

[7] Cameron, Teaching language to young learners. Cambridge: Cambridge University Press, 2001.

[8] G. Broughton, C. Brumfit, R. Flavell, P. Hill and A. Pincas, University of London Institute of Education Teaching English as a Foreign Language second edition. London and New York, 1980.

[10] G. Broughton and C. Bumfit, Teaching English as a Foreign Language. The Taylor and Francis e-Library, 2003.

[11] Penny McKay, Assessing Young Language Learner. Cambridge University Press. 2006.

[12] K. Kartono, Psikologi Anak. Bandung: penerbit Alumi, 1979.

[13] A. Taylor, Sound Great Single-letter Sounds, 2015.

[14] R.C. Bogdan and S.K. Biklen, Qualitative Research for Education: An Introduction to Theory and Method. Boston: Allyn and Bacon. Inc. 1982.

[15] M.B. Miles and A.M. Huberman, Qualitative Data Analysis. London: Sage Publishers, 1994.

[16] L.J. Moleong, Metodologi Penelitian Kualitatif. Bandung: Remaja Rosdakarya, 2002. 